\title{
Olive mill wastewater characteristics: modelling and statistical analysis
}

\author{
By Luísa C. Davies*, André M. Vilhena, Júlio M. Novais and Susete Martins-Dias
}

Centre of Biological and Chemical Engineering, Instituto Superior Técnico, Av. Rovisco Pais, 1049-001 Lisboa,Portugal. Fax.+351 2184190 62, e-mail: pcluisa@popsrv.ist.utl.pt

\section{RESUMEN}

\author{
Características del alpechín: modelos y análisis esta- \\ dístico.
}

Presentamos una síntesis de los trabajos realizados en los últimos 50 años relacionados con la caracterización del alpechín. Realizamos una recopilación de los datos publicados, buscando correlaciones entre los datos relativos al alpechín y los compuestos fenólicos. Esto permite la determinación de las características del alpechín a partir de una sola medida: La concentración de compuestos fenólicos.

Proponemos dos modelos, uno basado en datos relativos a seis países y un segundo aplicado unicamente a Portugal. El análisis estadístico de las correlaciones obtenidas indica que la demanda química de oxígeno de un determinado alpechín es una función polinómica de segundo grado de su concentración de compuestos fenólicos.

Se comprobó la significancia de esta correlación mediante la aplicación del análisis multivariable ANOVA, y además se evaluó la distribución de residuos y sus promedios a un nivel de fiabilidad del 95 y 99\%. Este trabajo ayudará al diseño futuro de plantas de tratamiento de alpechín, así como a su funcionamiento y control.

PALABRAS-CLAVE: Características del Alpechín - Compuestos Fenólicos - Demanda Química de Oxígeno - Modelos.

\section{SUMMARY}

Olive mill wastewater characteristics: modelling and statistical analysis.

A synthesis of the work carried out on Olive Mill Wastewater (OMW) characterisation is given, covering articles published over the last 50 years. Data on OMW characterisation found in the literature are summarised and correlations between them and with phenolic compounds content are sought. This permits the characteristics of an OMW to be estimated from one simple measurement: the phenolic compounds concentration. A model based on OMW characterisations from 6 countries was developed along with a model for Portuguese OMW. The statistical analysis of the correlations obtained indicates that the Chemical Oxygen Demand of a given OMW is a second-degree polynomial function of its phenolic compounds concentration. Tests to evaluate the significance of regressions were carried out, based on multivariable ANOVA analysis, on visual standardised residuals distribution and their means for confidence levels of 95 and $99 \%$, clearly validating these models. This modelling work will help in the future planning, operation and monitoring of an OMW treatment plant.

KEY-WORDS: Chemical Oxygen Demand (COD) - Modelling - Olive Mill Wastewater (OMW)- OMW characteristics-Phenolic compounds.

\section{INTRODUCTION}

Olive Mill Wastewater (OMW) is generated in the production of olive oil. Its treatment is a major environmental problem in Mediterranean countries, where the generation rate is very high and concentrated in a short period of time (NovemberFebruary). The annual OMW production is estimated to be over $30 \times 10^{6} \mathrm{~m}^{3}$ (Hamdi, $1993 \mathrm{a}$; Yesilada et al., 1995; Paredes et al., 1996), despite the efforts to implement two-phase, clean extraction technology.

The composition of OMW is very variable and depends on olive variety, the ripeness of the fruit, and the extraction process (press or centrifuge) (Lopez \& Ramos-Cormenzana, 1996).

Typical OMW composition by weight is: $83-94 \%$ water, $4-16 \%$ organic compounds and $0.4-2.5 \%$ mineral salts. The organic fraction contains, among other components, $2-15 \%$ of phenolic compounds divided into low-molecular weight (caffeic acid, tyrosol, hydroxytirosol, p-cumaric acid, ferulic acid, syringic acid, protocatechuic acid etc.) and high molecular weight compounds (tannins, anthocianins, etc) (Cabrera et al., 1996; Fiestas Ros Ursinos \& Borja-Padilla, 1996; Chung et al., 1998) as well as catechol-melaninic polymers (Ranalli, 1991).

In the bibliographic research, the majority of the articles found presented Chemical Oxygen Demand (COD) determinations, which ranged from 1.9 to $220 \mathrm{kgm}^{-3}$ (Alba, 1994; Passarinho, $2002)$; the Biochemical Oxygen Demand $\left(\mathrm{BOD}_{5}\right)$ is not commonly determined, however it was found to vary from 16.0 to $93.5 \mathrm{kgm}^{-3}$ (Fernandéz et al., 1989; Saviozi et al., 1991); in the same context it was found that the Total Solids (TS) varied from 5.9 to 103.2 $\mathrm{kgm}^{-3}$, the Volatile Solids (VS) varied from 2.4 to 89.9 $\mathrm{kgm}^{-3}$ (Alba, 1994; Hamdi, $1993 \mathrm{~b}$ ) and that the content of polyphenols (PhC) varied from 0.1 to 17.5 $\mathrm{kgm}^{-3}$ (Alba, 1994; Hamdi, 1993 a). The high content of organic matter and polyphenols together with the very large volumes produced and the seasonality of the industry has led to considerable pollution and has limited the application of conventional methods of wastewater treatment (Yesilada et al., 1995).

In this article we present a compilation of all data we could find from OMW studies published over the last 50 years. From this survey only those whose polyphenol compound concentration (PhC) was expressed in terms of caffeic acid equivalents were selected. The characterisations carried out for Portuguese OMWs were also considered. The final 
Table I

Bibliographic references for OMW characterisations

\begin{tabular}{|c|c|}
\hline $\begin{array}{l}\text { Year of } \\
\text { Publication }\end{array}$ & $\begin{array}{c}\text { Bibliographic } \\
\text { Reference }\end{array}$ \\
\hline 1988 & 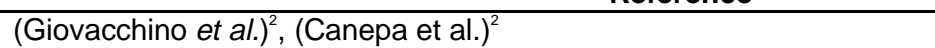 \\
\hline 1989 & (Fernandéz \& García) $^{2},(\text { Rannali) })^{2}$ \\
\hline 1990 & (Borja et al.) $)^{1}$, (Fiestas et al. $)^{1}$, (García García et al..) ${ }^{1}$ \\
\hline 1991 & $(\text { Borja et al.. })^{1},(\text { Hamdi \& Garcia) })^{3},(\text { Maestroet al. })^{1}$, (Saviozzi et al. $)^{2}$ \\
\hline 1992 & (Borja et al., a , b, c and d) \\
\hline 1993 & (Hamdi, a and b) $)^{3}$, (Bonari et al.) $)^{2}$, (Martinez et al..) ${ }^{1}$, (Sayadi \& Ellouz $)^{5}$ \\
\hline 1994 & $(A l b a)^{1}$ \\
\hline 1995 & (Borja et al., a and b) \\
\hline 1996 & 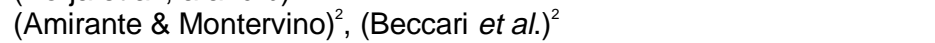 \\
\hline 1997 & ${\text { (Israilides et al. })^{4},(\text { Javier et al. })^{1}}$ \\
\hline 1998 & $(\text { Andreozzi et al. })^{2}$ \\
\hline 1999 & (Beccari et al. $a$ and $b)^{2}$, (Catalano et al. $)^{2}$, \\
\hline 2000 & $(\text { García et al. })^{1},\left(\right.$ Heredia et al., a and b) ${ }^{1},(\text { Improlive })^{7},(\text { Robles et al., })^{1}$ \\
\hline 2001 & $(\text { Aktas et al. })^{4}$, (Rivas et al. $)^{1}$ \\
\hline 2002 & $(\text { Davies })^{6},(\text { Fountoulakis et al. })^{4}$, (Passarinho) ${ }^{6}$ \\
\hline
\end{tabular}

Note: Source Countries: 1Spain, 2 Italy, 3 France, 4 Greece, 5 Tunisia, 6 Portugal, 7 other countries.

Table II

Portuguese OMW characterisation from 6 olive mills operating in 2002/2003 campaign

\begin{tabular}{lcccccc}
\hline & $\begin{array}{c}\text { Olive mill } \\
\text { I }\end{array}$ & $\begin{array}{c}\text { Olive mill } \\
\text { II }\end{array}$ & $\begin{array}{c}\text { Olive mill } \\
\text { III }\end{array}$ & $\begin{array}{c}\text { Olive mill } \\
\text { IV }\end{array}$ & $\begin{array}{c}\text { Olive mill } \\
\text { V }\end{array}$ & $\begin{array}{c}\text { Olive mill } \\
\text { VI }\end{array}$ \\
\hline pH & 6.85 & 5.02 & 4.24 & 5.02 & 4.92 & 5.50 \\
COD $\left(\mathrm{kgm}^{-3}\right)$ & 9.08 & 44.6 & 20.6 & 134 & 135 & 23.0 \\
BOD $\left(\mathrm{kgm}^{-3}\right)$ & 4.75 & nd & 11.0 & 40.0 & 42.0 & 7.90 \\
PhC $\left(\mathrm{kgm}^{-3}\right)$ & 0.03 & 2.54 & 0.61 & 5.40 & 6.16 & 0.25 \\
TS $\left(\mathrm{kgm}^{-3}\right)$ & 7.30 & 33.1 & 15.1 & 117 & 106 & 18.8 \\
VS $\left(\mathrm{kgm}^{-3}\right)$ & 7.10 & 28.4 & 9.80 & 94.3 & 79.2 & 12.9 \\
\hline
\end{tabular}

nd - not determined.

compilation includes 85 different evaluations of OMWs composition from more than 6 Mediterranean countries.

The data are summarised and correlations between the most commonly measured parameters are sought. A mathematical model relating COD to $\mathrm{PhC}$ is obtained and tested. The aim is to be able to estimate the characteristics of an OMW from one simple measurement: the phenolic compounds concentration, the eventual goal being to use this in the planning, operation and monitoring of an OMW treatment plant.

\section{EXPERIMENTAL PROCEDURE}

A literature survey was carried out and the parameters usually used to characterise OMW were selected. The most common parameters found were: $\mathrm{COD}, \mathrm{BOD}_{5}, \mathrm{PhC}, \mathrm{TS}$ and VS, with $\mathrm{PhC}$ concentration and COD by far the most common parameters determined. The Portuguese OMW characterisation was carried out by the determination of the aforementioned parameters according to Standard Methods (APHA, 1995).

\subsection{Determination of phenolic compounds in solution}

\section{Folin-Denis Method}

This was based on oxireduction reactions between PhC and metallic ions, adapted from a method described by Maestro-Durán et al., 1991. Results were expressed in terms of milligrams of caffeic acid equivalent, as this was used as a reference substance.

\section{RESULTS AND DISCUSSION}

The modelling of OMW characteristics was studied using two different strategies, an exhaustive bibliographic research was carried out and 45 values of OMW characterisation were encountered and used for the model development, the second approach was the validation of the model proposed by the introduction of 40 different values from Portuguese OMW collected over the last 8 years in traditional and continuous olive mills. 
Table III

Useful relationships between BOD, PhCs, TS, VS and COD and VS with TS

\begin{tabular}{|c|c|c|c|c|}
\hline & \multicolumn{2}{|c|}{ Literature } & \multicolumn{2}{|c|}{ Portuguese } \\
\hline & Average & & Average & \\
\hline $\mathrm{BOD} / \mathrm{COD}$ & $0.49 \pm 0.17$ & $\begin{array}{c}\text { Min } 0.20 \\
\text { Max } 0.88\end{array}$ & $0.40 \pm 0.10$ & $\begin{array}{r}\operatorname{Min} 0.30 \\
\operatorname{Max} 0.52\end{array}$ \\
\hline $\mathrm{PhC} / \mathrm{COD}$ & $0.05 \pm 0.04$ & Min 0.01 & $0.05 \pm 0.02$ & Min 0.01 \\
\hline TS/COD & $0.55 \pm 0.32$ & $\begin{array}{c}\operatorname{Max} 0.19 \\
\operatorname{Min} 0.56 \\
\operatorname{Max} 0.94\end{array}$ & $0.66 \pm 0.11$ & $\begin{array}{r}\operatorname{Max} 0.07 \\
\operatorname{Min} 0.25 \\
\operatorname{Max} 0.87\end{array}$ \\
\hline VS/COD & $0.59 \pm 0.25$ & $\begin{array}{c}\text { Min } 0.21 \\
\operatorname{Max} 0.91\end{array}$ & $0.58 \pm 0.11$ & $\begin{array}{c}\text { Min } 0.45 \\
\text { Max } 0.78\end{array}$ \\
\hline VS/TS & $0.70 \pm 0.24$ & $\begin{array}{c}\text { Min } 0.66 \\
\operatorname{Max} 0.87\end{array}$ & $0.79 \pm 0.09$ & $\begin{array}{r}\operatorname{Min} 0.65 \\
\operatorname{Max} 0.97\end{array}$ \\
\hline
\end{tabular}

It is important to take into account that the values collected from the bibliographic survey, Table I, concern different OMW source countries, different fruit varieties, ripeness and different extraction systems (pressing and centrifuging). For the Portuguese case the same aforementioned variables were considered, in this case the source country was obviously the same, as were the analytical procedures used for the OMW characterisation as described above.

Note that for the modelling work, besides the Portuguese values found in bibliographic references, experimental values for Portuguese OMW from the $2002 / 2003$ campaign were also considered. These values are summarised in Table II.

The first step was the compilation of all the data, after which some useful analytical relations were determined based on the average values of COD, BOD, PhC, TS and VS, as shown in Table III.

It is important to highlight the good agreement between the standard deviation of the ratios found in the literature and the ones determined for the Portuguese case. The average BOD represents 40 $-49 \%$ of the average COD, the average PhC $5 \%$, and the average TS and VS 55-66 \%. The ratio of VS to TS is roughly $70-80 \%$.

In the olive oil extraction process the $\mathrm{PhC}$ reach a heterogeneous equilibrium, resulting in their partition between the organic and liquid phases, based on their affinities. Phenolic compounds found in olive oil are attributed a beneficial effect for the consumers health, due to their antioxidant effect in removing free-radicals, which are molecules involved in chronic diseases (Luchetti, 2001). To the PhC found in the liquid phase is attributed an antimicrobial and phytotoxic effect; these are the most recalcitrant compounds found in OMW (Ranalli, 1991; Fadil et al., 2003) and one of the limiting factors in the efficiency of conventional treatments, such as chemical treatment (Chackchouk et al., 1994), and biological treatment (Hamdi \& Garcia, 1991; Borja et al., 1995, Beccari et al., 1996).
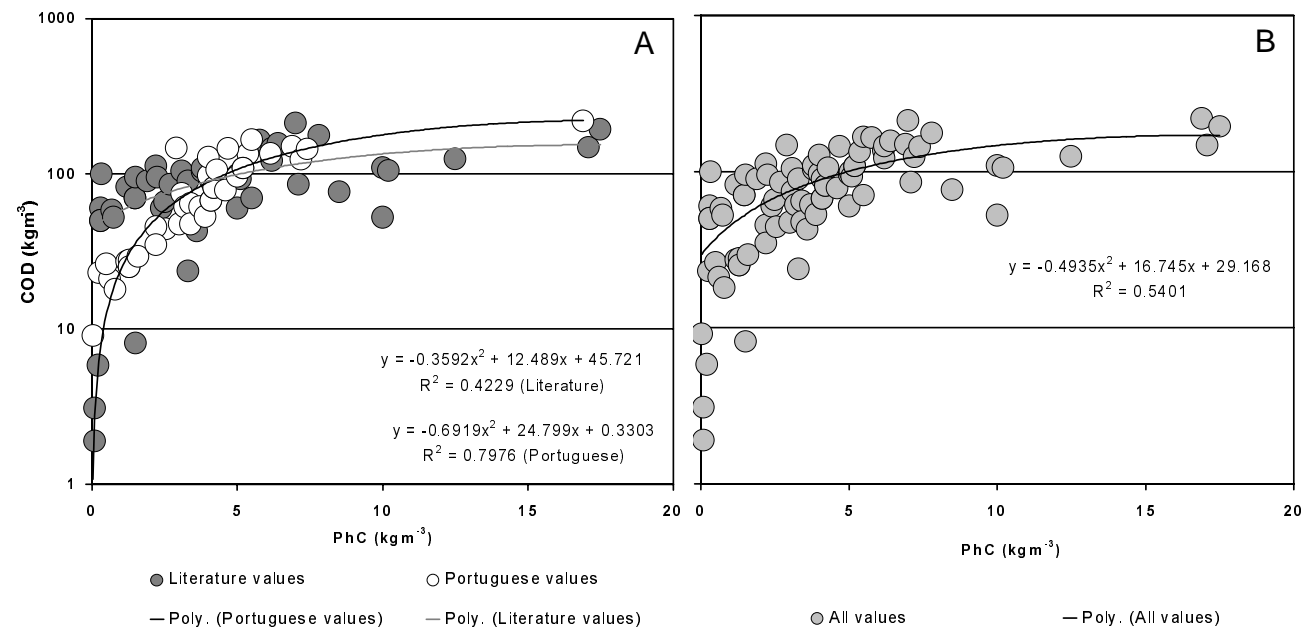

Figure 1

Second-degree polynomial function applied to A) literature and Portuguese values separately B) literature and Portuguese values together 

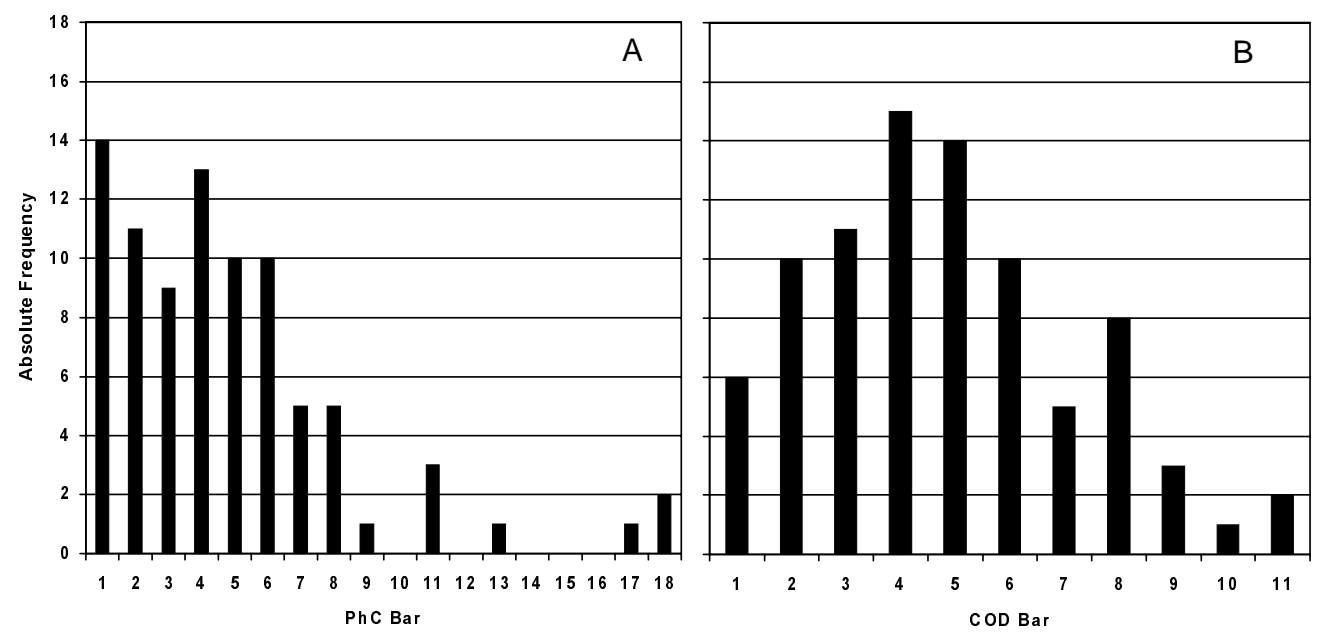

Figure 2

Histograms of A) $\mathrm{PhC}$ and B) COD absolute frequencies

\subsection{Model development}

The values found in the literature and the Portuguese values were considered separately, as shown in Figure 1-A, and altogether, as shown in Figure 1-B. They were fitted with a second-degree polynomial function. For the literature values the correlation parameter $\left(R^{2}\right)$ was 0.4229 , for the Portuguese values it was much higher at 0.7976 , and for all the values it was 0.5401 .

In order to define the boundaries of the model, tables of absolute frequencies of PhC values and COD values were constructed, using class intervals of $1 \mathrm{kgm}^{-3}$ and $20 \mathrm{kgm}^{-3}$ respectively. Bar charts are shown in Figure 2, with the intervals being given in Table IV.

For $\mathrm{PhC}$, Figure 2-A, the values are concentrated between 0 and $8 \mathrm{kgm}^{-3}$. The distribution between 0 and $6 \mathrm{kgm}^{-3}$ appears to be approximately uniform, considering the expected statistical fluctuations of $1 /(N)^{0,5}$, where $N$ is the number of values in the interval. This would define the normal working limits of an OMW treatment plant.

There is a clear, but small, decrease in the number of values in the range 6 to $8 \mathrm{kgm}^{-3}$, followed by a very sharp fall: of the total of 85 values only 8 stand in the range 8 to $18 \mathrm{kgm}^{-3}$. To explain these higher values, correlations between extraction systems were sought, but no plausible explanation was found, so it may be attributed to a statistical fluctuation. There are noticeable peaks in the PhC values in the ranges of 0 to 1 and 3 to $4 \mathrm{kgm}^{-3}$, however only the lower peak may be considered statistically significant. It was noticed that Portuguese OMWs with $\mathrm{PhC}$ in this interval had largely been collected at the outlet of the centrifuge of a two-phase extraction system, where the olive oil separation is carried out. In two-phase systems there are two exit lines, one for the olive husk, which is a combination of olive pulp and stone with the olive vegetation water, and one for the olive oil. In order to increase olive oil extraction yield, water is injected into the centrifuge, which is often designated as olive oil washing water, giving a dilute OMW. The current tendency in olive mills is to convert to two-phase extraction systems, which could be the reason for this peak in $\mathrm{PhC}$ absolute frequency.

In Figure $2 \mathrm{~B}$ ) the distribution is Gaussian-like, with COD values from 40 to $100 \mathrm{kgm}^{-3}$ occurring most frequently. This information is crucial for the conception, design, scale-up and optimisation of OMW treatment plants.

A matrix was constructed, as shown in Table V, combining the $\mathrm{PhC}$ and $\mathrm{COD}$ absolute frequencies. This clearly illustrates that there is a correlation between $\mathrm{PhC}$ and COD values. For the lower values, highlighted dark grey in Table $\mathrm{V}$, the correlation is clearly linear, whereas for the higher $\mathrm{PhC}$ values COD increases more slowly.

The low frequency of PhC values, together with the absence of values in some intervals for high $\mathrm{PhC}$ concentration, led us to base the model only on $\mathrm{PhC}$ concentrations up to $8 \mathrm{kgm}^{-3}$, as presented in Figure $3 \mathrm{~A}-\mathrm{B}$.

The main feature in these representations is that for this range both second-degree polynomial and linear functions fit well, with $\mathrm{R}^{2}$ being very similar for both of them. However, when PhC increases above the range considered here there is not a corresponding increase in COD, and a saturation point is reached. This is reproduced, for the total range of values we have, by the second-degree polynomial (Figure 1).

Although linearity is observed for low PhC concentrations, the second-degree polynomial model is preferable because it fits well for high and low concentrations. 
Table IV

PhC and COD concentration intervals

\begin{tabular}{|c|c|c|c|}
\hline \multicolumn{2}{|r|}{ PhC } & \multicolumn{2}{|r|}{ COD } \\
\hline Bar Chart & Class intervals $\left(\mathrm{kgm}^{-3}\right)$ & Bar Chart & Class intervals $\left(\mathrm{kgm}^{-3}\right)$ \\
\hline 1 & $0<1$ & 1 & $0<20$ \\
\hline 2 & $1<2$ & 2 & $20<40$ \\
\hline 3 & $2<3$ & 3 & $40<60$ \\
\hline 4 & $3<4$ & 4 & $60<80$ \\
\hline 5 & $4<5$ & 5 & $80<100$ \\
\hline 6 & $5<6$ & 6 & $100<120$ \\
\hline 7 & $6<7$ & 7 & $120<140$ \\
\hline 8 & $7<8$ & 8 & $140<160$ \\
\hline 9 & $8<9$ & 9 & $160<180$ \\
\hline 10 & $9<10$ & 10 & $180<200$ \\
\hline 11 & $10<11$ & 11 & $200<220$ \\
\hline 12 & $11<12$ & & \\
\hline 13 & $12<13$ & & \\
\hline 14 & $13<14$ & & \\
\hline 15 & $14<15$ & & \\
\hline 16 & $15<16$ & & \\
\hline 17 & $16<17$ & & \\
\hline 18 & $17<18$ & & \\
\hline
\end{tabular}

Table V

Matrix of COD and $\mathrm{PhC}$ absolute frequencies

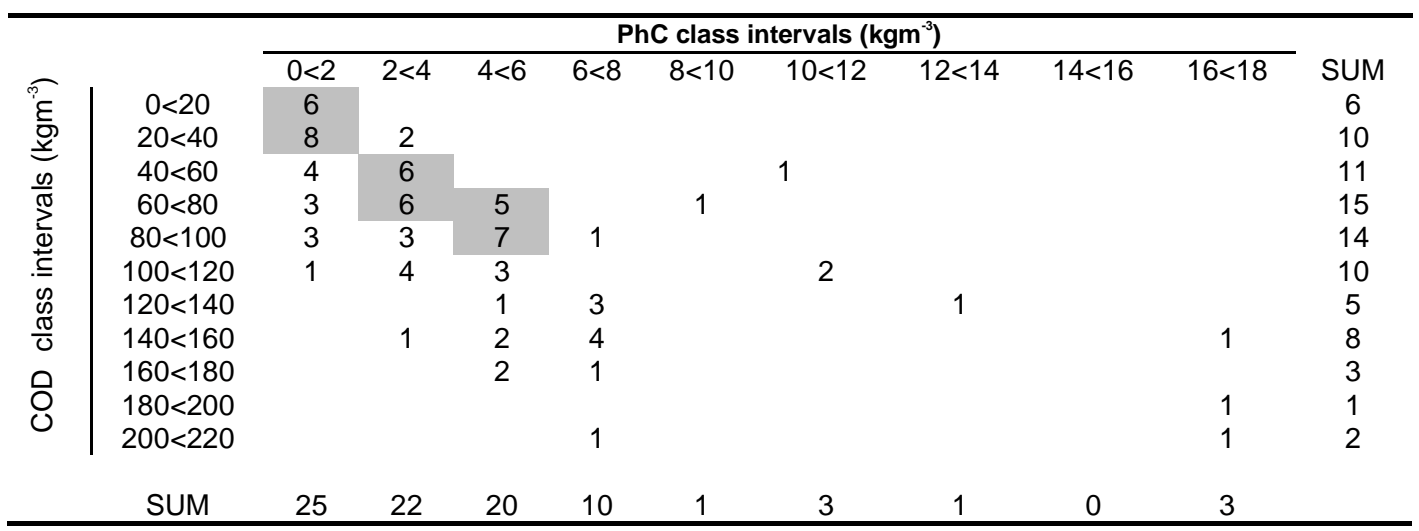
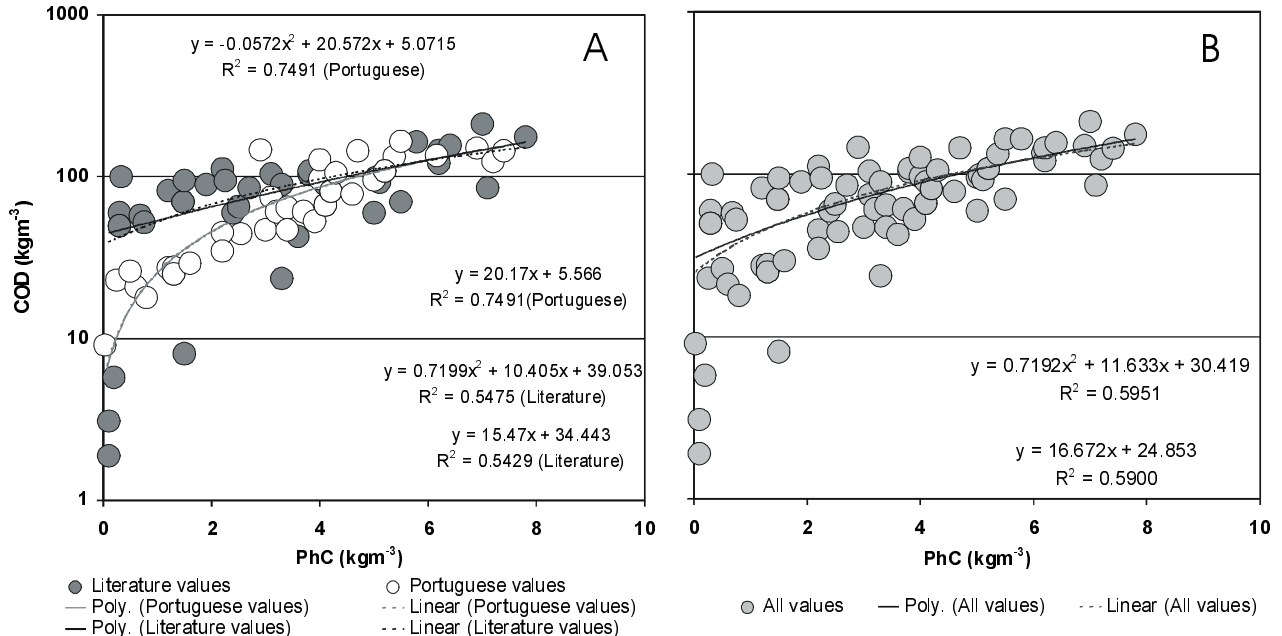

- Poly. (Literature values) _... Linear (Literature values)

Figure 3

Linear and Second-degree polynomial functions applied to A) literature and Portuguese values B) all values together; for $\mathrm{PhC}$ concentrations up to $8 \mathrm{kgm}^{-3}$ 


\subsection{Test for the Significance of the Regressions}

$\mathrm{R}^{2}$ gives the amount of variability in the data explained or accounted by the model regressions. The regressions presented in Figure 1 account for $42.29 \%$ and $79.76 \%$ and $54.01 \%$ of the variability in the data for literature, Portuguese and all values together, respectively. However, a large value of $R^{2}$ doesn't necessarily imply that the model is a good one, because this parameter does not measure the statistical significance of a regression. For example, a regression applied to two points will have an $R^{2}$ of 1 , but it has no statistical significance. In order to assess these empirical models adequacy an ANOVA table for each type of data (literature, Portuguese and all) and a residual analysis were studied. The models are summarized in Figure 4.

There is good agreement between the regressions for the literature values and for all values together.

To the regressions obtained for the literature values, the Portuguese values and all the values together which are given by the following equations:

\section{Literature values:}

$$
\begin{gathered}
\mathrm{COD}_{i, \text { predicted value }}=-0.3592\left(\mathrm{PhC}_{i, \text { measured value }}\right)^{2} \\
+12.489\left(\mathrm{PhC}_{i, \text { measured value }}\right)+45.721
\end{gathered}
$$

\section{Portuguese values:}

$$
\begin{aligned}
& \mathrm{COD}_{i, \text { predicted value }}=-0.6919\left(\mathrm{PhC}_{i, \text { measured value }}\right)^{2} \\
& +24.799\left(\mathrm{PhC}_{i, \text { measured value }}\right)+0.3303
\end{aligned}
$$

All Values:

$$
\begin{aligned}
& \mathrm{COD}_{i, \text { predicted value }}=-0.4935\left(\mathrm{PhC}_{i, \text { measured value }}\right)^{2} \\
& +16.745\left(\mathrm{PhC}_{i, \text { measured value }}\right)+29.168
\end{aligned}
$$

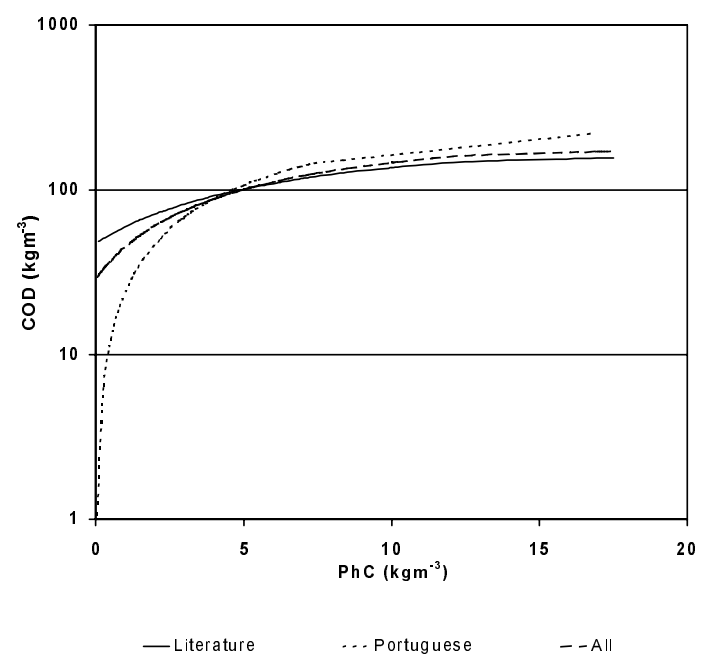

Figure 4

Model simulations for $\mathrm{PhC}$ varying from 0 to $17.5 \mathrm{kgm}^{-3}$
It was performed a significance test as suggested by Montgomery and Runger (1999). For a regression of the type, $Y=\beta_{2} x^{2}+\beta_{1} x+\beta_{0}$, this test tries to determine whether a linear relationship exists between the response variable $y$ (COD) and a subset of the regressor variables $x(\mathrm{PhC})$ and $\mathrm{x}^{2}$ $\left(\mathrm{PhC}^{2}\right)$. The appropriate hypotheses are:

$$
H_{0}: \beta_{1}=\beta_{2}=0
$$

$$
\mathrm{H}_{1}: \beta_{\mathrm{j}} \neq 0 \text { for at least one } j
$$

Rejection of $\mathrm{H}_{0}: \beta_{1}=\beta_{2}=0$ implies that at least one of the regressor variables contributes significantly to the model.

The parameters obtained from a multivariable analysis are given in Table VI.

Since the P-value is considerably smaller than = 0.05 , we reject the null hypothesis and conclude that $\mathrm{COD}$ is linearly related to either $(\mathrm{PhC})$ or $(\mathrm{PhC})^{2}$ or both.

Further tests of model adequacy are required before we can comfortably use this model in practice, such as residual analysis.

\subsubsection{Residual Analysis}

Standardized residuals from the multiple regression model are defined by

$$
d_{i}=e_{i}\left(\mathrm{MS}_{\mathrm{E}}\right)^{0.5}
$$

Where $e_{i}$ is $C O D_{i}$, measured value $-C O D_{i}$,predicted value and $M S_{E}$ is the Mean Square Error

Standardized residuals were calculated and plotted against $C O D_{i}$,predicted value, as is shown in Figure 5. From visual analysis, the residuals are independently distributed. The mean residual values are $-5.34 \times 10^{-2} \pm 0.29,4.48 \times 10^{-5} \pm 0.31$, and -2.95 $\times 10^{-5} \pm 0.21$ for the literature values, Portuguese values and all values, respectively, for a confidence level of $95 \%$ and $-5.34 \times 10^{-2} \pm 0.39,4.48 \times 10^{-5} \pm$ 0.42 , and $-2.95 \times 10^{-5} \pm 0.28$ for a confidence level of $99 \%$. In all circumstances the mean residual values are almost zero, validating the use of a second-order polynomial. As the regressions found for the literature and the Portuguese values are similar, it makes sense to consider only one model, accounting for all of the values.

Both residual distribution analysis and the mean residual values, with errors calculated for confidence levels of 95 and $99 \%$, indicate that the model is more accurate for all of the values, thus equation 3 is to be preferred.

However, when a Portuguese OMW is being considered, equation 2 may be preferred, as it refers specifically to this case, and the error is only marginally higher than for equation 3 . 
Table VI

ANOVA table parameters for the literature values, Portuguese values and all the values together

\begin{tabular}{|c|c|c|c|c|c|}
\hline & \multicolumn{5}{|c|}{ Literature Values } \\
\hline Item & $\begin{array}{l}\text { Degrees of } \\
\text { Freedom }\end{array}$ & $\begin{array}{l}\text { Sum of } \\
\text { Squares }\end{array}$ & $\begin{array}{l}\text { Mean } \\
\text { Square }\end{array}$ & F Statistic & P-value \\
\hline Model & 2 & 43265 & 21633 & 15.41 & $<0.0001$ \\
\hline Error & 41 & 58973 & 1404 & & \\
\hline \multirow[t]{2}{*}{ Total } & 43 & 102238 & & & \\
\hline & \multicolumn{5}{|c|}{ Portuguese Values } \\
\hline Item & $\begin{array}{l}\text { Degrees of } \\
\text { Freedom }\end{array}$ & $\begin{array}{l}\text { Sum of } \\
\text { Squares }\end{array}$ & $\begin{array}{l}\text { Mean } \\
\text { Square }\end{array}$ & F Statistic & $P$-value \\
\hline Model & 2 & 78751 & 39375 & 72.92 & $<0.001$ \\
\hline Error & 37 & 19991 & 540 & & \\
\hline \multirow[t]{2}{*}{ Total } & 39 & 98742 & & & \\
\hline & \multicolumn{5}{|c|}{ All Values } \\
\hline Item & $\begin{array}{l}\text { Degrees of } \\
\text { Freedom }\end{array}$ & $\begin{array}{l}\text { Sum of } \\
\text { Squares }\end{array}$ & $\begin{array}{l}\text { Mean } \\
\text { Square }\end{array}$ & F Statistic & $\mathrm{P}$-value \\
\hline Model & 2 & 109425 & 54712 & 48.16 & $<0.001$ \\
\hline Error & 83 & 93161 & 1136 & & \\
\hline Total & 84 & 202586 & & & \\
\hline
\end{tabular}

\section{CONCLUSIONS AND FUTURE WORK}

Despite the fact that the OMW characteristics were obtained from different countries, with different olive varieties, from different years, from mills with different extraction processes and were obtained using different techniques in different laboratories, a good correlation between $\mathrm{COD}$ and $\mathrm{PhC}$ is found using a second-degree polynomial.
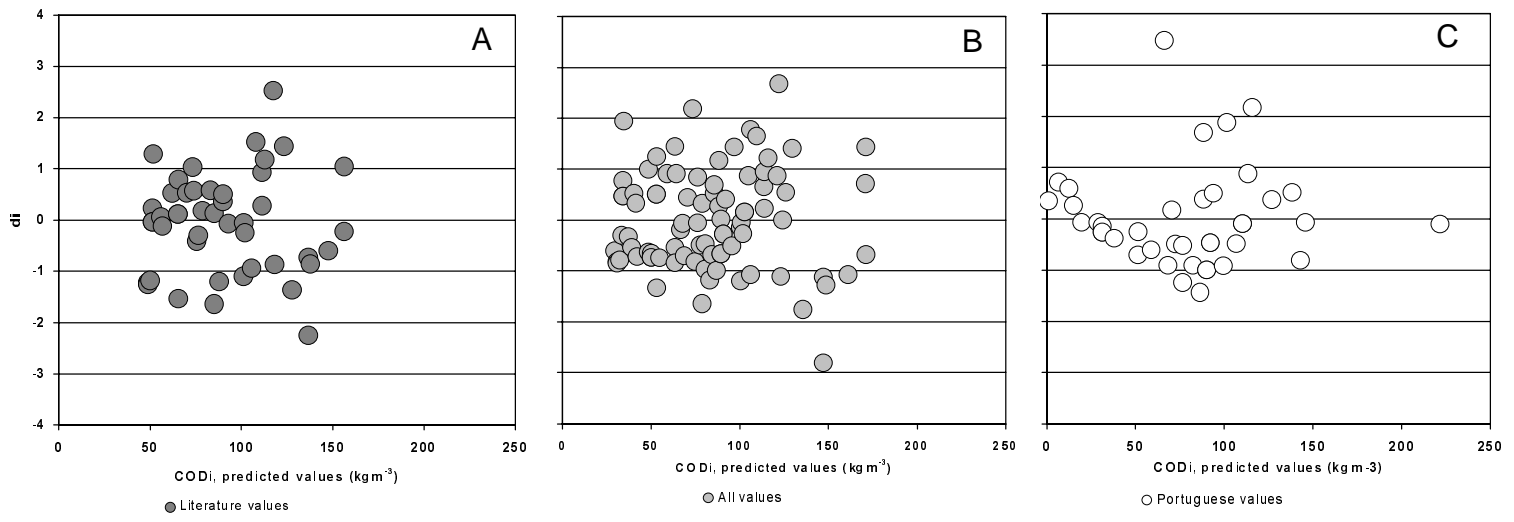

Figure 5

Standardized residuals from multiple regression model against COD predicted values for A) literature B) Portuguese and C) all values together
The model developed may be useful not only in the conception of OMW treatment plants but also for their monitoring, allowing less time to be spent on analysis.

After a multivariable analysis with P-values considerably smaller than $\alpha=0.05$, a visual residual analysis independently distributed and their mean residual values for a confidence level of 95 and $99 \%$ being zero, the models proposed in this study were 
validated. In the future the models will be improved by the inclusion of more values from OMW characterisations, and their optimisation will be pursued.

\section{ACKNOWLEDGMENTS}

Luísa C. Davies acknowledges Fundação para a Ciência e a Tecnologia, Ministério da Ciência e Tecnologia, Portugal, for supporting this study with a PhD grant.

The authors wish to thank Dr. Jonathan Robert Davies for the English revision and Dr. Mario Gómez for the Spanish abstract.

\section{REFERENCES}

Aktas, E.S., Imre, S., Ersoy, L. (2001). Characterization and lime treatment of olive mill wastewater. Water Res., 9, 2336-2340

Alba, J. (1994). Nuevas tecnologías para la obtención del aceite de oliva. Fruticultura Profesional (Suplemento), 62, 85-95.

Amirante, P. \& Montervino, A. (1996). Depuración por concentración térmica de los efluentes de las almanzares y compostización del concentrado. Una experiencia en Apulia. OLIVAE, 63, 64-68.

Andreozzi, R., Longo, G., Majone, M., Modesti, G., (1998). Integrated treatment of olive mill effluents (OME): Study of ozonation coupled with anaerobic digestion. Water Res., 32, 8, 2357-2364.

APHA (American Public Health Association), (1995) Standard Methods for the examination of water and wastewater, $19^{\text {th }}$ Ed., Eaton A., Clesceri L., Greenberg A.,Washington, D.C.

Beccari, M., Bonemazzi, F., Majone, M. \& Riccardi, C. (1996). Interactions between acidogenesis and methanogenesis in the anaerobic treatment of olive oil mill effluents. Water Res., 30, 183-189.

Beccari, M., Caricci, G., Majone, M. \& Torrisi, L. (1999 a). Role of lipids and phenolic compounds in the anaerobic treatment of olive oil mill effluents. Environ. Technol., 20, 105-110.

Beccari, M., Majone, M., Riccardi, C., Savarese, F. \& Torrisi, L. (1999 b). Integrated treatment of olive oil mill effluents: Effect of chemical and physical pretreatment on anaerobic treatability. Water. Sci.Technol., 40, 347-355.

Bonari, E., Macchia, M., Angelini, L.G. \& Ceccarini, L. (1993). The waste waters from olive oil extraction: their influence on germinative characteristics of some cultivated and weed species. Agricoltura Mediterranea, 123, 273-280.

Borja Padilla, R., Martín Martín, A. \& Fiestas Ros de Ursinos, J.A. (1990). Estudio cinético de la depuración anaerobia del alpechín en presencia de diversos soportes para la inmovilización de los microorganismos responsables del proceso. Grasas y Aceites, 41, 347-356.

Borja, R., Martín Martín, A., Maestro Durán, R., Alba Mendonza, J. \& Fiestas Ros de Ursinos, J.A. (1991). Cinética del proceso de depuración anaerobia de alpechín previamente biotratado via anaeróbia. Grasas y Aceites, 42, 194-210.

Borja, R., Martín Martín, A., Durán Barrantes, M.M. \& Maestro Durán, R. (1992 a). Estudio cinético comparativo del proceso de digestión anaerobia del alpechín en los intervalos mesofílicos y termofílicos de temperatura. Grasas y Aceites, 43, 341-346.

Borja, R., Alba Mendonza, J. \& Durán Barrantes, M.C. (1992 b). Influencia de los coadyuvantes tecnológicos utilizados en el proceso de elaboración de aceite de oliva sobre la cinética del proceso de digestión anaerobia del alpechín. Grasas y Aceites, 43, 204-211.

Borja, R., Alba Mendonza, J. \& Luque González, M. (1992 c). Depuración aerobia de los efluentes resultantes del proceso de biometanización del alpechín. Grasas y Aceites, 43, 20-25.

Borja Padilla, R., Martín Martín, A., Durán Barrantes, M.M. $(1992$ d). Estudio cinético del proceso de biometanización de alpechín de almanzara clásica previamente sometido a tratamiento aerobio con Geotrichum candida. Grasas y Aceites, 43, 82-86.

Borja, R. , Martín, A., Alonso, V., García, I. \& Banks, C.J. (1995 a). Influence of different aerobic pretreatments on the kinetics of anaerobic digestion of olive mill wastewater. Water Res., 29, 489-495.

Borja, R., Alba, J., Garrido, S.E., Martinez, L., García, M.P., Incerti, C. \& Ramos-Cormenzana, A. (1995 b). Comparative study of anaerobic digestion of olive mill wastewater (OMW) and OMW previously fermented with Aspergillus terreus. Bioprocess Eng., 13, 317-322.

Cabrera, F., López, R., Martinez-Bordiú, A., Dupuy de Lome, \& E., Murillo, J.M., (1996). Land treatment of olive oil mill wastewater. Int. Biodeter. Biodegr , 38:215-225.

Canepa, P., Marignetti, N., Rognoni, U. \& Calgari, S. (1988). Olive mills wastewater treatment by combined membrane processes, Water Res., 12, 1491-1494.

Catalano, L., Franco, I., Nobili, M. \& Leita, L. (1999). Polyphenols in olive mill waste waters and their depuration plant effluents: a comparison of the Folin-Ciocalteau and HPLC methods. Agrochimica, 43(5-6), 193-205.

Chackchouk, M., Hamdi, M., Foussard, J.N. \& Debellefontaine, H. (1994). Complete treatment of olive mill wastewaters by a wet air oxidation process coupled with a biological step. Environ. Technol., 15, 323-332.

Chung, K., Wei, C. \& Johnson, M. (1998). Are tannins a double-edged sword in biology and health?. Trends in Food Sci. and Technol., 9, 168-175.

Davies, L. (2002). Olive Mill Wastewater valorisation as organic fertilizer by superabsorbent polymers, MSc Thesis, Instituto Superior Técnico, Universidade Técnica de Lisboa, Portugal.

Durán, M., Padilla, B., Martin, A., Fiestas Ros de Ursinos, A. \& Mendoza, J., (1991). Biodegradación de los compuestos fenólicos presentes en el alpechin. Grasas y Aceites, 42 (4):271-276.

Fadil, K., Chahlaoui, A., Ouahbi A., Zaid A. \& Borja R. (2003). Aerobic biodegradation and detoxification of wastewaters from the olive oil industry. Int. Biodeter. Biodegr., 51, 37-41.

Fiestas, J.A., Martín, A. \& Borja, R. (1990). Influence of immobilization supports on the kinetic constant of anaerobic purification of olive mill wastewater. Biological Wastes, 33, 131-142.

Fiestas Ros de Ursinos, J. \& Borja-Padilla, R., (1996). Biomethanization. Int. Biodeter. Biodegr., 38, 145-153.

Fernandéz, A.G. \& García, P.G. (1989). Purificación de aguas residuales ricas en polifenoles: aplicación de la oxidación húmeda a los efluentes acuosos derivados 
de las industrias olivareras. Grasas y Aceites, 40, 291-295.

Fountoulakis, M.S., Dokianakis, S.N., Kornaros, M.E., Aggelis, C.C. \& Lyberatos, G. (2002). Removal of phenolics in olive mill wastewaters using white-rot fungus Pleurotus ostreatus. Water Res., 36, 19, 4735-4744.

García García, P.(a), Fernández, A.G., Chakman, A., Lemonier, J.P., Overende, R.P. \& Chornet, E. (1990). Aplicación de la tecnología jet-reactor a la oxidación húmeda de las aguas residuales de las industrias derivadas del olivo. Grasas y Aceites, 41, 158-162.

García García, I. (b), Jiménez Peña, P.R., Bonilla Venceslada, J.L., Martín Martín, A., Martín Santos, M.A. \& Ramos Gómez, E. (2000). Removal of phenol compounds from olive mill wastewater using Phanerochaete chrysosporium, Aspergillus niger, Arpergillus terreus and Geotrichum candidum. Process Biochem., 35, 751-758.

Giovacchino, L.D., Mascolo, A. \& Seghetti, L. (1988). Sulle caratteristiche delle acque di vegetacione delle olive, Nota II. La Riv. Ital. Sostanze Grasse, 65, 481-487.

Hamdi, M. (1993 a). Future prospects and constraints of olive mill wastewaters use and treatment: $A$ review. Bioprocess Eng., 8:209-214.

Hamdi, M. (1993 b). Thermoacid precipitation of darkly coloured polyphenols of olive mill wastewater. Environ. Technol., 14, 495-500.

Hamdi, M. \& Garcia, J.L. (1991). Comparison between anaerobic filter and anaerobic contact process for fermented olive mill wastewater. Bioresource Technol., 8, 23-29.

Heredia Alonso, J.B., Torregrosa Antón J., García Rodríguez, J. \& Domínguez Vargas, J.R. (2000 a). Tratamiento con ozono de las aguas residuales de almazara. Grasas y Aceites, 51, 301-306.

Heredia Alonso, J.B. , Torregrosa Antón, J., García Rodríguez, J., Ramos Viseas, M.P. \& Domínguez Vargas, J.R. (2000 b). Tratamiento biológico aerobio de alpechín depurado previamente con ozono. Grasas y Aceites, 51, 332-339.

Improlive Project (FAIR CT96-1420) (2000). Improvements of treatment and validation of liquid-solid waste from the two-phase olive-oil extraction - Final Report Annex

A2. www.nf-2000.org/publications/f1420fin.pdf

Israilides, C.J., Vlyssides, A.G., Mourafeti, V.N. \& Karvouni, G. (1997). Olive oil wastewater treatment with the use of an electrolysis system. Bioresource Technol., 61, 163-170.

Javier Benitez, F., Beltrán-Heredia, J., Torregrosa, J. \& Acero, J.L. (1997). Treatment of wastewaters from olive oil mills by UV radiation and by combined ozone-UV radiation. Toxicological Environ. Chem., 61 (1-4), 173-185.
Lopez, M. \& Ramos-Cormenzana, A., (1996). Xanthan production from olive-mill wastewaters. Int. Biodeter. Biodegr., 38, 263-270.

Luchetti, F., (2001). Olive Oil: facts and figures. Lipid Technology, 13 (2), 32-36.

Montgomery, C.D., \& Runger, G.C. (1999) Applied statistics and probability for engineers, 2 nd Ed., John Wiley \& Sons, Inc., New York.

Maestro Durán, R., Borja Padilla, R., Martín Martín, A., Fiestas Ros de Ursinos, J.A. \& Alba Mendonza, J. (1991). Biodegradación de los compuestos fenólicos presentes en el alpechín. Grasas y Aceites, 42, 271-276.

Martinez Nieto, L., Garrido Hoyos, S.E., Camacho Rubio, F., Garcia Pareja, M.P. \& Ramos Cormenzana, A. (1993). The biological purification of waste products from olive oil extraction. Bioresource Technol., 43, 215-219.

Paredes, C., Bernal, M., Roig, A., Cegarra, J. \& Sánchez-Monedero, M. (1996). Influence of the bulking agent on the degradation of olive mill wastewater sludge during composting. Int. Biodeter. Biodegr., 38, 205-210.

Passarinho, P. (2002). Olive Mill Wastewater detoxification. $\mathrm{PhD}$ Thesis, Instituto Superior Técnico, Universidade Técnica de Lisboa, Portugal.

Ranalli, A. (1991). El efluente de las almazaras: propuestas para su utilización y depuración con referencias a la normativa italiana (primera parte). Olivae, 37, 30-39.

Rannali, A. (1989). Fermenti selezionati nel trattamento biologicoi delle acque reflue dei frantoi. Industrie Alimentari, 28, 141-148.

Rivas, F.J., Béltran, F.J., Gimeno, O. \& Frades, J. (2001). Treatment of olive oil mill wastewater by Fenton's reagent. J. Agric. Food Chem., 49, 1873-1880.

Robles, A., Lucas, R., Cinfuegos, G. \& Galvez, A. (2000). Biomass production and detoxification of wastewates from the olive oil industry by strain of Penicillium isolated from wastewater disposal pounds. Bioresource Technol., 74 (3), 217-221.

Sayadi, S. \& Ellouz, R. (1993). Screening of white rot fungi for the treatment of olive mill wastewaters. J. Chem. Tech. Biotechnology, 57, 141-146.

Saviozzi, A., Levi-Minzi, R., Riffaldi, R. \& Lupetti, A. (1991). Effeti dello spandimento di acque di vegetacione sul terreno agrario. Agrochimica, 35 (1-3), 135-147.

Yesilada O., Fiskin K. \& Yesilada E. (1995). The use of white rot fungus Funalia trogii (Malatya) for the decolourization and phenol removal from olive mill wastewater. Environ. Technol., 16, 95-100.

Recibido: Febrero 2003 Aceptado: Noviembre 2003 